Available online at GSC Online Press Directory

GSC Biological and Pharmaceutical Sciences

e-ISSN: 2581-3250, CODEN (USA): GBPSC2

Journal homepage: https://www.gsconlinepress.com/journals/gscbps

(RESEARCH ARTICLE)

\title{
Performance of West African dwarf goats fed cassava peels treated with nitrogen sources
}

\author{
Ajagbe Adekunle David, Oyewole Benjamin Osigbodi *, Aribido Samson Oluwatoyin and Sunday Peter \\ Adejoh
}

Department of Animal Production, Kogi State University, Anyigba, Kogi State, Nigeria.

Publication history: Received on 18 December 2019; revised on 09 January 2020; accepted on 11 January 2020

Article DOI: https://doi.org/10.30574/gscbps.2020.10.1.0247

\begin{abstract}
A feeding trial was carried out for 60 days with 40 growing West African Dwarf (WAD) bucks aged 5 - 7 months with an initial weight of $5.25 \mathrm{~kg} \pm 0.35$ to determine their performance characteristics. The goats were randomly allocated to five treatments, each treatment had eight replicates. The experimental diets were compounded such that Diet T1 had $100 \%$ urea treated cassava peel. T2 60\% untreated cassava peel, 40\% cassava foliage. T3 60\% untreated cassava peel, $40 \%$ poultry manure, T4 60\% untreated cassava peel, 20\% cassava foliage and 20\% treated cassava peel. T5 $60 \%$ untreated cassava peel, $20 \%$ cassava foliage, $20 \%$ poultry manure. The average live weight gain was significant $(\mathrm{P}<0.05)$ across the treatment groups with T1 having higher value. Average daily weight gain ranged between 19.59 and 20.30(g/d) with $\mathrm{T} 1$ showing significantly $(\mathrm{P}<0.05)$ higher value than other treatment groups. Feed conversion ratio was also best with Diet T1. It can be concluded that urea treated cassava peels enhanced better performance of growing WAD goats in the tropics especially in dry season when there is decline of natural herbage.
\end{abstract}

Keywords: Urea; Cassava foliage; Poultry manure; Buck; Treated

\section{Introduction}

Livestock production is an important venture in the economy of developing countries. Goats particularly play an important role in the livelihood of small scale farmers as a major component of livestock mixed farming systems, which produce meat, milk, skin, fibre, and manure to large number of low income earners [1]. The complex factor that affects livestock production is nutrition, as feed resources are limited in quantity and quality. The systems of goat production in Nigeria are usually characterized by limitations posed by non-availability of year- round feed resources due to prolonged dry season of northern Nigeria [2]. Goats are multi-purpose animals producing meat, milk and skin and hairs. However, out of these products, meat is the major form in which goats are consumed in Nigeria [3]. Goat meat is widely accepted and consumed in Nigeria because there is no taboo against it [4]. The demand for goat meat is very high especially in rural areas where it often commands higher market price than beef. Meat from goat is preferable to those from other animal species because of its flavour, tenderness and palatability [5]. The meat-goat industry has grown, providing many new opportunities for additional income on diversified farming operations. Meat-goat producers will need feeds that are economical and easily managed. The use of cassava peel, poultry manure and cassava foliage as nonconventional feed stuffs for goat production has generated much attention besides the availability of large quantities of cassava peel, cassava foliage and poultry manure which are often left to rot, thereby constituting environmental problem. There is need to put these wastes into productive use besides attempting to ameliorate the high cost of goat production and also providing cheaper animal protein to the populace. This study evaluated the performance characteristics of growing goats fed cassava peel treated with different nitrogen sources.

\footnotetext{
${ }^{*}$ Corresponding author

E-mail address: oyewole.bo@ksu.edu.ng
} 


\section{Material and methods}

This experiment was conducted at the Sheep and Goat Unit of the Teaching and Research Farm of Kogi State University, Anyigba in accordance with the Institution's animal ethical committee guideline. Anyigba lies between latitude $7^{\circ} 5^{\prime} \mathrm{N}$ and $7^{\circ} 21^{\prime} \mathrm{E}$ of the equator and longitude $7^{\circ} 11^{\prime} \mathrm{N}$ and $7^{\circ} 32^{\prime} \mathrm{E}$ of the Greenwich meridian, with an altitude of about $420 \mathrm{~m}$ above sea level. The zone is characterized by 6-7 months of average annual rainfall of about $1600 \mathrm{~mm}$ and the daily temperature ranges between $25^{\circ} \mathrm{C}$ and $35^{\circ} \mathrm{C}$ [6]. Fresh cassava peels, free from stumps were collected and grated before being subjected to hydraulic press for dewatering. The dewatered peels were then pulverized and sieved to obtain the coarse mash, which was then sun-dried for 2-3days before being loaded into bags for feeding animals. Cassava foliage was harvested fresh and sundried until the leaves became brittle for milling. Poultry manure was obtained from poultry enterprise that installed battery cage system, and sundried for 5-7 days, to enable easy milling. Four kilogramme (4kg) of urea fertilizer was dissolved in 100 litres of water and then used to treat $100 \mathrm{~kg}$ of cassava peels by spraying. The product was then pressed together to eliminate air while in the container. The product in the container was then covered with plastic sheet and ensiled for 21 days before being used for diet formulation [7]. Five supplementary experimental diets (Table 1) were compounded namely; T1 (100\% urea treated cassava peel), T2 (60\% untreated cassava peel $+40 \%$ cassava foliage), T3 (60\% untreated cassava peel $+40 \%$ poultry manure), T4 (60\% untreated cassava peel $+20 \%$ cassava foliage $+20 \%$ treated cassava peel) and T5 (60\% untreated cassava peel $+20 \%$ cassava foliage $+20 \%$ poultry manure) [8] .

A total of forty (40) West African Dwarf bucks of about 5-7 months, with initial weights of $5.25 \mathrm{~kg} \pm 0.35$ were obtained from goat producers within Anyigba Town, and used for the feeding trial which lasted for 60 days [8]. The goats were treated against ecto-parasites and endo-parasites, besides vaccination against peste des petits ruminants (PPR).The goats were randomly assigned to five treatments in a Completely Randomized Design (CRD), and each treatment was replicated eight times. A 14 day adjustment period was allowed for the goats before data collection commenced. The experimental goats were allowed to graze for about 7 hours around Kogi State University Teaching and Research Farm, after which, they were fed supplementary rations based on 3\% body weight. All goats in each treatment replicate were served feed and water ad libitum. Data on feed intake by individual animal was recorded daily and left over feed was weighed and subtracted from the total quantity offered to determine the daily feed intake. The average daily feed intake was obtained by dividing the total feed intake by the number of experimental days. Animals were weighed at the beginning of the experiment and subsequently weekly in the morning before feeding to determine the weight gain. Feed conversion ratio was determined as the ratio of intake to weight gain. Data collected were subjected to analysis of variance (ANOVA) and differences between treatment means were separated by Duncan using Statistical Software Package- Statistical Package for Social Sciences (SPSS) version 20.

Table 1 Gross composition (\%) of experimental diets for growing West African dwarf goats

\begin{tabular}{|c|c|c|c|c|c|}
\hline Ingredients & T1 & T2 & T3 & T4 & T5 \\
\hline Cassava Peel Meal+ Urea & 100 & - & - & 20 & - \\
\hline Untreated Cassava peel Meal & - & 60 & 60 & 60 & 60 \\
\hline Poultry Manure & - & - & 40 & _- & 20 \\
\hline Cassava Foliage & - & 40 & - & 20 & 20 \\
\hline Total & 100 & 100 & 100 & 100 & 100 \\
\hline
\end{tabular}

\section{Results}

\subsection{Supplementary feed and dietary nutrient composition}

The gross and proximate compositions of supplementary diets are shown in Table 2.The organic matter (OM) content of the concentrate supplements ranged between 94.23 and $95.18 \%$ while the crude protein values vary from $9.95 \%$ to $11.89 \%$. The dry matter contents of the diets were $82.38 \%$ in T5 to $85.60 \% \mathrm{~T} 1$.The Crude protein content of the treatment diets varied between $9.95 \%$ and $11.89 \%$ while the crude fibre content of the diets ranged from $9.68 \%$ to $10.95 \%$. The values obtained for ether extract in this study ranged from $2.99 \%$ to $3.25 \%$. Ash content of the supplementary diets ranged from $4.85 \%$ to $5.77 \%$ while the nitrogen free extracts ranged from $52.59 \%$ to $56.02 \%$. The acid detergent fibre and neutral detergent fibre ranged from $15.90 \%-31.85 \%$ and $29.22 \%-50.01 \%$ respectively. The hemicellulose content of the treatment diets ranged from $11.42 \%-18.16 \%$. 
Ajagbe et al. / GSC Biological and Pharmaceutical Sciences 2020, 10(01), 009-012

Table 2 Proximate composition of supplements for growing West African dwarf goats (\%)

\begin{tabular}{llllll}
\hline Nutrient & T1 & T2 & T3 & T4 & T5 \\
\hline Dry Matter & 85.60 & 83.23 & 83.63 & 84.40 & 82.38 \\
Organic Matter & 94.45 & 94.75 & 94.23 & 94.85 & 95.18 \\
Crude Protein & 9.95 & 11.89 & 11.09 & 10.70 & 10.89 \\
Crude Fibre & 10.95 & 10.25 & 10.62 & 10.15 & 9.68 \\
Ether Extract & 3.13 & 3.25 & 3.25 & 3.20 & 2.99 \\
Ash & 5.55 & 5.25 & 5.77 & 5.15 & 4.85 \\
Nitrogen Free Extract & 56.02 & 52.59 & 52.63 & 55.20 & 54.00 \\
Nuetral Detergent Fibre & 29.22 & 39.95 & 50.01 & 29.00 & 39.73 \\
Acid Detergent Fibre & 17.80 & 26.05 & 31.85 & 15.90 & 25.23 \\
Hemicellulose & 11.42 & 13.90 & 18.16 & 11.42 & 14.50 \\
\hline
\end{tabular}

The performance characteristics of growing WAD goats fed cassava peel treated with different nitrogen sources is presented in Table 3. Feed intake, body weight gain and feed conversion ratio were significantly $(\mathrm{P}<0.05)$ different across the dietary treatments. All the experimental animals had adequate total feed intake, which ranged from 512.27 $\mathrm{g} /$ day to $565.37 \mathrm{~g} /$ day across the treatments. The total daily feed intake obtained in this study is higher than the value reported by [9] who fed WAD goats with urea treated cassava peels as supplement to grazing natural pasture. Average daily gains significantly $(P<0.05)$ varied, and ranged from $19.59-20.30 \mathrm{~g} /$ day, with goats on Diet T1 having higher gain. Feed conversion ratio was best $(\mathrm{P}<0.05)$ with $\mathrm{T} 1$ and worst with $\mathrm{T} 2$. The better feed conversion ratio for $\mathrm{T} 1$ is comparable to the report of [9] who fed $4 \%$ urea treated cassava peel to goats. The possible reason for better performance of animals in $\mathrm{T} 1$ might be attributed to the urea treatment in which the cassava peel was subjected to which made the fermentable nitrogen more available in the rumen thereby bringing about better performance. This is in harmony with the report of [10] who opined that urea treatment improved weight gain of ruminant animals. Urea treatment of cassava peels could have increased microbial digestion and amount of digesta that moved through the gastro-intestinal tract with consequent increase in performance indices of animals.

Table 3 Performance of growing West African dwarf goats fed cassava peel treat with nitrogen sources

\begin{tabular}{llccccc}
\hline Parameters & \multicolumn{1}{c}{ T1 } & T2 & T3 & T4 & T5 & SEM \\
\hline Initial Weight (kg) & 5.32 & 5.33 & 5.31 & 5.50 & 5.50 & - \\
Final Weight (kg) & 6.78 & 6.51 & 6.50 & 6.93 & 6.74 & - \\
Average Weight Change(kg) & $1.46^{\mathrm{a}}$ & $1.26^{\mathrm{b}}$ & $1.19^{\mathrm{c}}$ & $1.43^{\mathrm{a}}$ & $1.24^{\mathrm{b}}$ & 0.02 \\
ForageIntake(g/d) & $410.50^{\mathrm{a}}$ & $400.20^{\mathrm{a}}$ & $380.40^{\mathrm{b}}$ & $390.10^{\mathrm{b}}$ & $381.10^{\mathrm{b}}$ & 12.34 \\
Supplement Intake(g/d) & $106.67^{\mathrm{d}}$ & $115.17^{\mathrm{c}}$ & $131.83^{\mathrm{a}}$ & $115.00^{\mathrm{c}}$ & $119.67^{\mathrm{b}}$ & 10.03 \\
Total Daily Feed Intake (g/d) & $517.17^{\mathrm{b}}$ & $565.37^{\mathrm{a}}$ & $512.23^{\mathrm{b}}$ & $505.60^{\mathrm{c}}$ & $500.77^{\mathrm{c}}$ & 0.27 \\
Average DailyGain(g/d) & $20.30^{\mathrm{a}}$ & $19.73^{\mathrm{b}}$ & $19.59^{\mathrm{b}}$ & $20.05^{\mathrm{a}}$ & $19.69^{\mathrm{b}}$ & 0.19 \\
Feed Conversion Ratio & $25.47^{\mathrm{d}}$ & $28.66^{\mathrm{c}}$ & $31.24^{\mathrm{a}}$ & $25.68^{\mathrm{d}}$ & $27.92^{\mathrm{b}}$ & 1.06
\end{tabular}

$\mathrm{T} 1=100 \%$ Urea treated cassava peel, T2 =60 \% untreated cassava peel $+40 \%$ cassava foliage, T3 =60 \% untreated cassava peel $+40 \%$ poultry manure

$\mathrm{T} 4=60 \%$ untreated cassava peel $+20 \%$ cassava foliage $+20 \%$ urea treated cassava peel $\mathrm{T} 5=60 \%$ untreated cassava peel $+20 \%$ cassava foliage $+20 \%$ poultry manure

\section{Conclusion}

It can be concluded that treatment of cassava peels with urea resulted in better performance of growing WAD goats. 


\section{Compliance with ethical standards}

\section{Acknowledgments}

The Authors wish to acknowledge the Management of Kogi State University Anyigba for the provision of facility at the Livestock Teaching and Research Farm that was used for the feeding trial. We are also indebted to the Technical Staff members of the Livestock Teaching and Research Farm of Kogi State University Anyigba for their kind support.

\section{Disclosure of conflict of interest}

All authors declare no conflict of interest exists.

\section{References}

[1] Acharya SN, Iwaasa AD, McAllister TA, Wang Y and Thomas J. (2011). Animal performance and incidence of bloat in mixed Alfalfa/sainfoin grazing; Plant Canada 2011, Saint Mary's University, Halifax, NS, Canada July 17-21.

[2] Anaeto M, Tayo GO, Chioma GO, Ajao AO and Peters TA. (2009). Health and Nutrition Practices among Small holder Sheep and Goat Farmers in Ogun State, Nigeria. Livestock Research for Rural Development, 21(11).

[3] Alikwe PCN, Faremi AY, Fajeminsin AN and Akinsoyinu OA. (2011). Performance and nitrogen utilization of West African Dwarf goats fed soybean and dried poultry waste- based concentrates as supplement to Cynodon nlemfuensis basal diet Journal of Applied Sciences in Environmental Sanitation, 6(2), 189-191.

[4] PeacockC. (1996).Improving goat production in the tropics.A manual for development workers. An oxfarm /Farm Africa Publication (UK and Ireland), 1-20.

[5] Idiong NB and Orok EJ. (2008). Acceptability of some fodder plants by West African Dwarf goats. Journal of Agriculture, Technology, Business and Applied Sciences, 1 (1), 33-37

[6] Ifatimehin O0, Musa SD and Adeyemi JO. (2006). Managing land use transformation and land surface temperature in Anyigba town, Kogi State, Nigeria. Journal of Geography and Geology, 3, 77-85.

[7] Puck B, Arno M and Jolianne R. (2004). Dairy cattle management. Agrodok- series (14), 23.

[8] Ajagbe DA, Aribido SO, Oyewole BO and Egwuje CO. (2019). Hematology and Serum Biochemistry of Growing West African Dwarf Goats Fed Cassava Peel with Supplemental Nitrogen Sources. Agricultural Extension Journal, 3(3). 1-6.

[9] Uza DV, Barde RE and Ayoade JA. (2005). The Effects of Urea Treated Cassava Peels as Supplements to West African Dwarf goats grazing Natural pasture. Nigerian Veterinary Journal, 26(1), 1-9.

[10] Ifut OJ. (1992). The potential of cassava peel for feeding goat in Nigeria. In: Potential Utilization of cassava as livestock feed in Africa. Editors: Hanh SK, Reynoids L and Egbunike GN. Workshop Proceedings, IITA Ibadan, Nigeria, 72-81.

\section{How to cite this article}

Ajagbe AD, Oyewole BO, Aribido SO and Sunday PA. (2020). Performance of West African dwarf goats fed cassava peels treated with nitrogen sources. GSC Biological and Pharmaceutical Sciences, 10(1), 09-12. 